\title{
Comparison between a piezoelectric device and rotary instruments in implant site preparation: an in vivo morphological, histological analysis using pigs
}

Comparação entre o sistema piezoelétrico e fresas na preparação de nichos para implantes: análise morfológica tecidual in vivo em suinos

\author{
Gilson SAKITA ${ }^{1}$ \\ Sergio ALLEGRINI JUNIOR ${ }^{1}$ \\ Marcos Barbosa SALLES² \\ Marcos Pearce Cirilo BATISTA ${ }^{3}$ \\ Luciana Yazawa PISTARINI ${ }^{1}$ \\ Reinaldo Macedo FRAGA ${ }^{1}$ \\ Marcelo YOSHIMOTO ${ }^{1}$
}

\section{ABSTRACT}

\section{Objective}

To carry out a histological comparison, at different postoperative periods, of bone tissue repair after implant site preparations on the tibia of pigs using both a piezoelectric device and rotary instruments.

\section{Methods}

Surgical procedures were performed on the tibia of four pigs. Five perforations were made in the left tibia using star shaped piezosurgery tips (Piezosonic Driller ${ }^{\circledR}$ ) and five perforations in the right tibia using carbon coated rotary drills (DSP Biomedical ${ }^{\circledR}$ ). The pigs were then sacrificed at $2,7,14$, and 28 days. The tibiae were removed and the tissues were prepared for histological processing and analysis under a light microscope.

Results

The histological analyses showed similar results at 2 days and both groups presented inflammatory infiltrate. At 7 days, the drill system produces a regular surface preparation and the process of bone repair was greater when compared with the piezoelectric device. At 14 days the presence of new bone formation was more intense with the drill system. However, at 28 days both systems showed similar results, with the presence of an organized, newly formed bone tissue.

\section{Conclusion}

It was possible to conclude that both implant site preparations, using the piezoelectric device and rotatory instruments, resulted in similar bone neoformation at 28 days.

Indexing terms: Bone regeneration. Osteogenesis. Osteotomy. Piezosurgery.

\section{RESUMO}

\section{Objetivo}

Comparar os aspectos histomorfológicos do tecido ósseo após osteotomias realizadas em tíbias de suínos com sistema piezoelétrico e instrumentos rotatórios em diferentes tempos pós-operatórios.

\section{Métodos}

Procedimentos cirúrgicos foram realizados em tíbias de quatro suínos, sendo que cada animal recebeu cinco perfurações na tíbia esquerda utilizando sistema piezoelétrico com pontas em forma de estrela (Piezosonic Driller ${ }^{\circledR}$ ) e cinco perfurações na tíbia direita utilizando fresas rotatórias com revestimento de carbono(DSP Biomedical ${ }^{\circledR}$ ). Os animais foram sacrificados nos tempos pós-operatórios de 2, 7, 14 e 28 dias. As tíbias foram removidas e o material foi processado para exame histológico em microscopia de luz.

\section{Resultados}

Ao exame histológico, observou-se após 2 dias, achados semelhantes para os 2 grupos, revelando a presença de tecido compatível com um coágulo junto a um infiltrado inflamatório no leito osteotomizado. Aos sete dias, os preparos realizados com fresas se mostraram mais regulares e houve sinais de maior neoformação óssea próxima ao tecido ósseo remanescente quando comparados ao sistema piezoelétrico. No grupo de 14 dias ficou evidente maior neoformação óssea ao longo de todo leito cirúrgico no grupo de fresas, enquanto o sistema piezoelétrico apresentou neoformação óssea dispersa, porém ao final de 28 dias, a análise morfológica tecidual foi semelhante em ambos os grupos, com a presença de trabeculado ósseo reorganizado.

\section{Conclusão}

Pode-se concluir que os achados da análise morfológica revelaram que tanto o sistema piezoelétrico como as fresas na preparação de nichos para implantes promoveram neoformação óssea semelhante, evidenciando a presença de trabeculado ósseo reorganizado aos 28 dias.

\section{Termos de indexação: Regeneração óssea. Osteogênese. Osteotomia. Piezocirurgia.}

\footnotetext{
${ }^{1}$ Universidade Ibirapuera - Unidade Chácara Flora. Av. Interlagos, 1329, Chácara Flora, 04661-100, São Paulo, SP, Brasil. Correspondência para / Correspondence to: G SAKITA. E-mail:<gilsonskt@uol.com.br>.

${ }^{2}$ Universidade Nove de Julho, Faculdade de Odontologia. São Paulo, SP, Brasil.

${ }^{3}$ Universidade Camilo Castelo Branco, Faculdade de Odontologia. São Paulo, SP, Brasil.
} 


\section{INTRODUCTION}

Conventional osteotomy techniques for inserting titanium implants are mainly performed with the use of rotary instruments and drill cutters. Despite the evolution of these instruments and the development of new techniques and materials, bone trauma is ever-present and the use of these instruments can cause damage to the bone tissue due to overheating during the surgical procedure and may increase the intensity of the inflammatory response. Piezoelectric surgery, which is a high-frequency surgical ultrasound system, has been advocated for carrying out precise, less invasive surgical procedures, the main advantages being the selective cutting of hard tissue and preservation of the soft tissue, less vibration and noise, absence of trauma in adjacent tissue, reduction in bleeding and an excellent view of the operative field ${ }^{1}$. Many studies have been published regarding osteotomies performed using piezoelectric instruments for the extraction of third molars ${ }^{2-6}$, in various categories of oral and maxillofacial surgery ${ }^{7-11}$ and even in orthodontic microsurgery ${ }^{12}$.

Specifically with regard to Implant Dentistry, piezoelectric instruments have been proposed for the removal of bone grafts ${ }^{13-15}$, the preparation of the bone window in sinus lift procedures ${ }^{16-18}$ and the lateralization, immobilization and transposition of the inferior alveolar nerve ${ }^{19-20}$

Few in vivo studies have appeared in the literature ${ }^{21-24}$ which have evaluated the histological aspects after using piezoelectric instruments when compared to the conventional rotary cutting system in the preparation of implant sites. Moreover, the results of these studies are contradictory as regards bone neoformation in the location of the traumatized bone tissue, resulting from injury after the use of the two types of instrument, piezoelectric and conventional.

The aim of this study was to compare the histomorphological aspects of the bone tissue after osteotomies performed on the tibias of pigs, using a piezoelectric system and rotary instruments, and taking into account different postoperative periods.

\section{METHODS}

This study was approved by the Committee on Animal Research and Ethics at the University Ibirapuera (UNIB), in São Paulo, Brazil. The sample comprised four female Landrace pigs aged around 55 days and with an average body weight of $20 \mathrm{~kg}$. The animals were kept in separate, clean and ventilated pens and they were provided with food and water ad libitum.

Ten perforations were made in each animal, five of which were in the right tibia, using rotary instruments (DSP Biomedica ${ }^{\circledR}$ ) while the other five perforations were made in the left tibia using the piezoelectric system (Piezosonic Driller $\left.^{\circledR}\right)$, to a depth of $10 \mathrm{~mm}$. All surgical procedures were carried out by the same dental surgeon, who was an implant dentist.

The animals were randomly sacrificed at 2, 7, 14 and 28 days after the operation. After the euthanasia, the tibias were removed and sent for histological processing for analysis under a light microscope.

\section{Surgical procedures}

The animals received anesthetic induction in the appropriate room and the drug Ketamine - $S(+) 50 \mathrm{mg} / \mathrm{ml}$ was used, combined with Midazolam $15 \mathrm{mg} / 3 \mathrm{ml}$, for the purposes of relaxation, thereby facilitating handling during bathing and the injectable and inhalational anesthetic procedures in the operating room.

The animals were then subjected to a disinfectant bath using a solution of chlorhexidine $2 \%$, and after 15 minutes they were taken to the surgery where the hypnotic drug Etomidate $2 \mathrm{mg} / \mathrm{ml}$ was administered intravenously with Pancuronium Bromide $2 \mathrm{mg} / \mathrm{ml}$ via infusion (Samtronic ST280 Infusion Pump).

Next came the oral intubation using mechanical ventilation (Takaoka Fuji ${ }^{\circledR}$ ) and inhalational anesthesia was administered using Isoflurane. For prophylactic purposes, Cefazolin Sodium $1 \mathrm{~g}$ and Fentanyl Citrate $0.0785 \mathrm{mg} / \mathrm{ml}$ were then applied, plus the analgesic Dipyrone to prevent pain.

The animals were stabilized on the operating table, thereby facilitating access to the bilateral surgical sites. External antisepsis with Povidone-lodine 10\% in the pre-operative area was followed by local anesthetic supplementation based on a Lidocaine 25 infiltration and Adrenaline $0.03 \mathrm{Ul} / \mathrm{ml}$ (DFL Laboratory).

A straight, even incision, approximately 6 centimeters long, was made in the region of the tibia using a no. 3 scalpel with a no. 15 blade, performing dissection in layers and subperiosteal detachment to expose the bone structure, maintaining separation using spacers of the Wolkman 4 type.

For the drilling performed with the group of rotary instruments, the rotary system with a Smart electric motor 
(Driller ${ }^{\circledR}$ ) was used, and 27:1 contra-angle hand-piece (Kavo) at a speed of $900 \mathrm{rpm}$. The drill cutters used in this group were specifically for dental implant use, of the helical, spear-type with a caliber of $2 \mathrm{~mm}$, pilot $2 / 3 \mathrm{~mm}$, and $3 \mathrm{~mm}$ (DSP Biomedical ${ }^{\circledR}$ ), with carbon coating (Figure 1A) The perforations were copiously irrigated using Sodium Chloride $0.9 \%$, performing intermittent back and forth movements helping to keep the apex of the drill cutters cool (Figure 1B).
Drillings using the piezoelectric system (Piezosonic Driller $^{\circledR}$ ) were carried out following the sequence of surgical drill burs, numbers ESO 18D, ESO 19D, ESO 40A, ESO 40B (Figure 2A), oscillating between 27 and $31 \mathrm{Khz}$ with a power of around 50W, cooled with a solution of Sodium Chloride $0.9 \%$ and using back and forth movements combined with gentle rotation, thereby facilitating the drilling (Figure 2B).
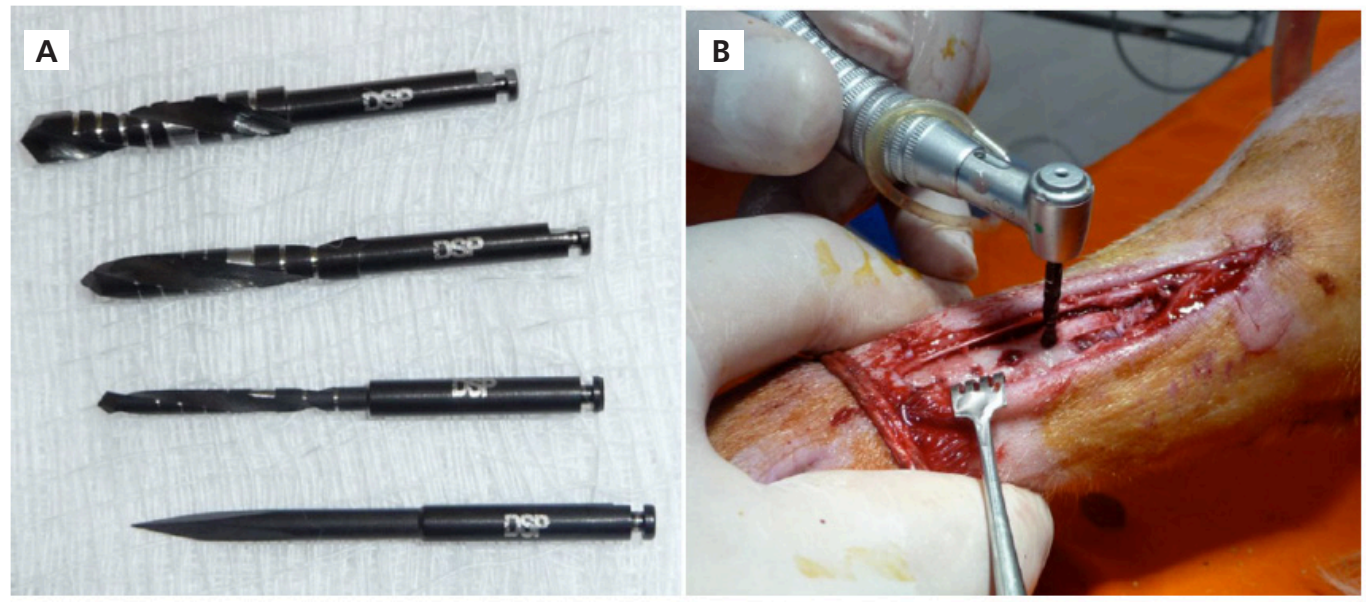

Figure 1. A) Cutters with carbon coating (DSP Biomedical ${ }^{\circledR}$ ) of conventional rotary system; B) Rotary cutting sequence in action using a system of cooling and the presence of controlled bleeding during drilling.

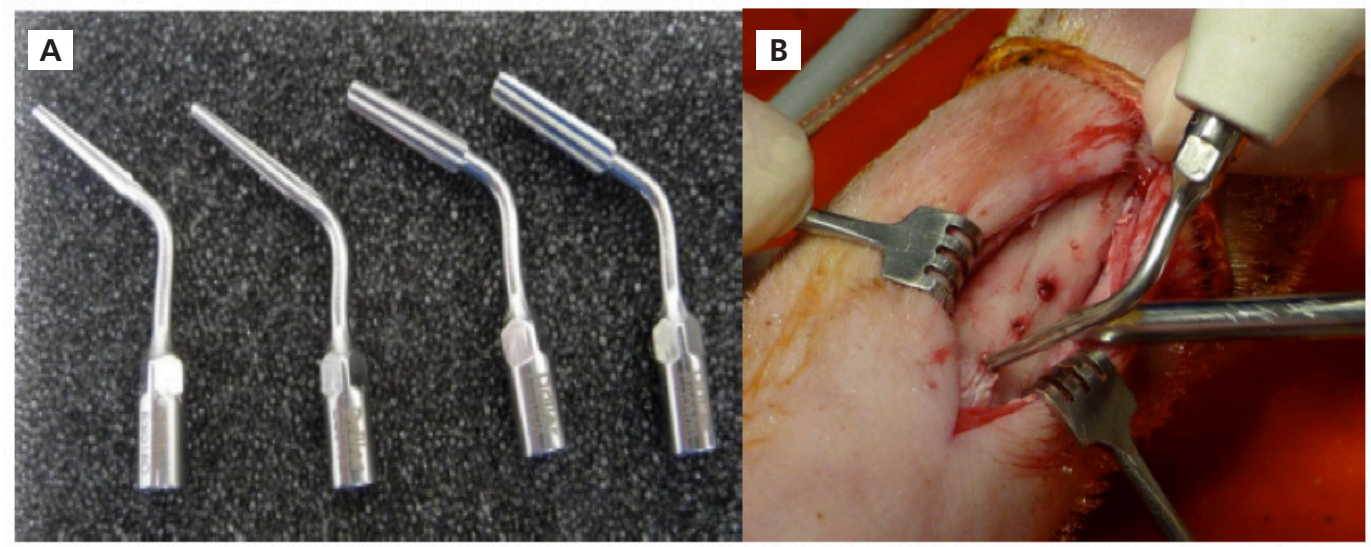

Figure 2. A) Ultrasonic tips Piezosurgery Piezosonic Driller® system; B) Piezosonic system Driller ${ }^{\circledR}$ at the point of drilling, the presence of an operative field without bleeding can be observed.

Once the osteotomies had been carried out, the tissues were repositioned and sutured using 3-0 nylon suture thread, followed by a fresh antisepsis with Povidonelodine $10 \%$, removing the presence of any residue from the skin. At the end of the experiment, the animals were kept in separate, clean and ventilated pens, with food and water ad libitum.
The animals were randomly sacrificed at 2, 7, 14 and 28 days after surgery. As for the euthanasia procedure, they were sedated with Ketamine - S(+) $50 \mathrm{mg} / \mathrm{ml}$ via intramuscular injection and they received Sodium Thiopental $2 \mathrm{~g}$ via intracardiac injection. After the euthanasia, the tibias were removed and cuts approximately $6 \mathrm{~mm}$ thick were made and the samples were stored using a fixing solution. 


\section{Preparation of the samples for morphological tissue analysis}

The samples were stored in hermetically sealed flasks for fixation in formaldehyde $10 \%$ for 48 hours.

The process of bone decalcification was performed using EDTA, for approximately 60 days, with replacement occurring every 3 days. After the decalcification, washing was carried out using running water for a period of 4 hours and each one was dehydrated for 30 minutes using alcohol in concentrations of $70 \%, 75 \%, 80 \%, 90 \%, 96 \%$ and finally, absolute alcohol.

Next came the diaphanization with a solution of xylene, replacing all the alcohol absorbed by the samples and then the process of impregnation and inclusion in paraffin at $60^{\circ} \mathrm{C}$ was carried out, twice, ensuring the exchange of all the clarifying agent by the paraffin. The block remained at room temperature until it had solidified and after this procedure, they were cut in a microtome to a thickness of 4 micrometers, clamping the section to a slide.
Hematoxicilin and Eosin staining was performed and the slides were analyzed and photographed under a bright field light microscope (Nikon Eclipse E1000) using the ACT-1 image capture program.

\section{RESULTS}

Histologically, the comparative results at 2 days demonstrated similar findings in the two groups studied. The presence was observed of tissue that was consistent with a clot, together with an inflammatory infiltrate in the osteotomized segment (Figures 3A and 3B). The edges of the osteotomized tissue in the initial third of the surgical preparation showed differences among the surfaces in the studied groups; in the piezoelectric group (Figure 3C) the surfaces exhibited irregular patterns while in the rotary group the presence of a smooth surface was evident (Figure 3D).
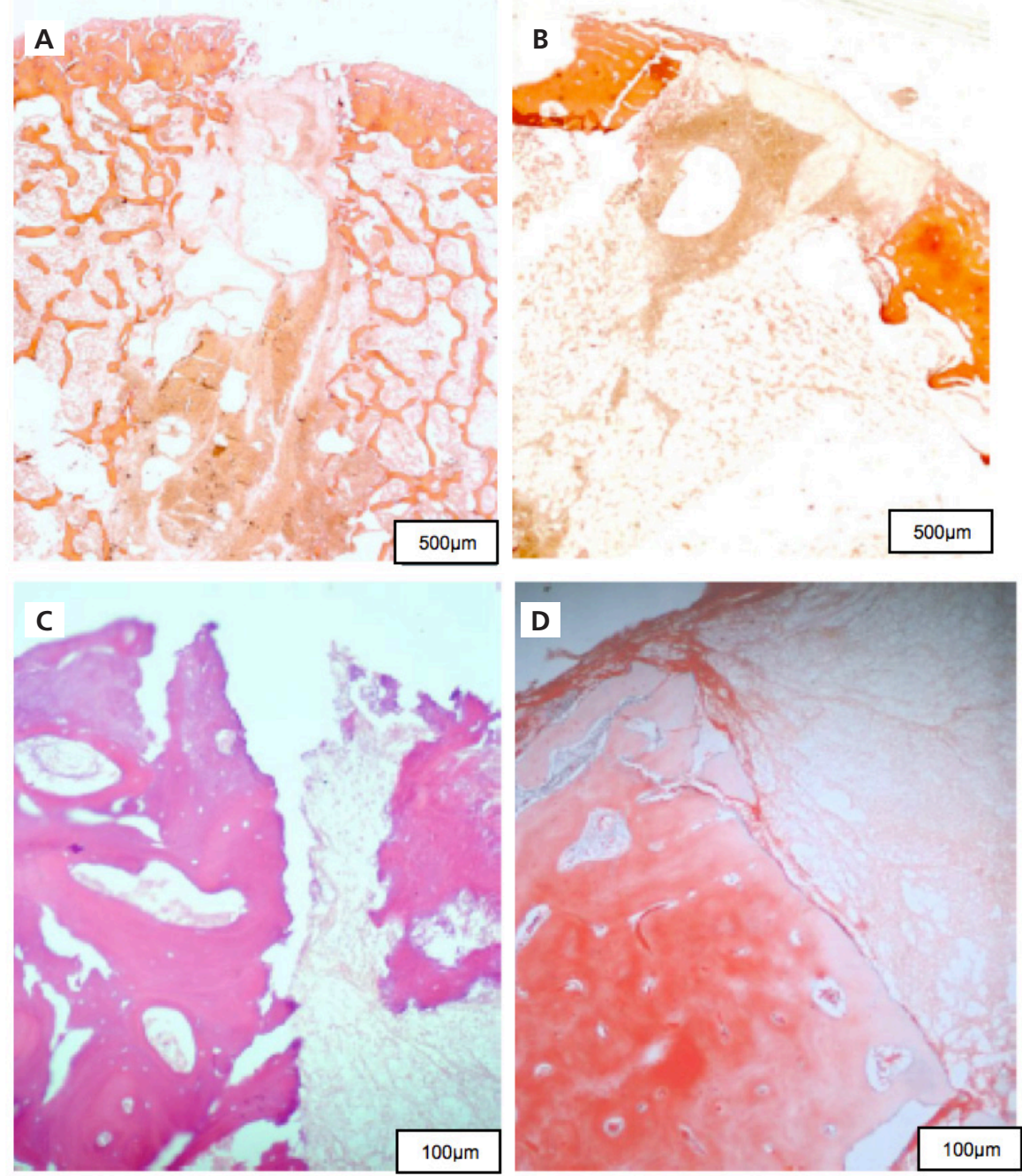

Figure 3. A) Piezo group 2 days - Inside the site preparation performed using the piezoelectric system; B) Drill cutter group 2 days: Inside the site preparation performed using the cutting system; C) Piezo group 2 days - Detail of the osteotomized edge using the piezoelectric system, evidencing an irregular surface; D) Drill cutter group 2 days - Detail of the osteotomized edge where the smooth surface of the site preparation conducted with a cutting system can be observed. 
At 7 days, greater osteogenesis was found with the rotary group, with the presence of a formation of bone trabeculae along the entire surgical site, while in the piezoelectric group the presence of scattered trabeculae was noted close to the marginal bone tissue remaining in the final third (Figures $4 \mathrm{~A}$ and $4 \mathrm{~B}$ ).

With the piezoelectric system at 14 days, was observed the presence of bone formation dispersed throughout the surgical site (Figure 5A), with a vascular stroma composed of adipose tissue, the presence of bone trabeculae with osteocytes and peripheral line (Figure 5C). In the group of rotary there was intense neoformation of thirds of cortical and medullary beginning with thicker trabecular bone in greater quantity and better organization (Figures $5 B$ and $D$ ) when compared with piezosurgery group.

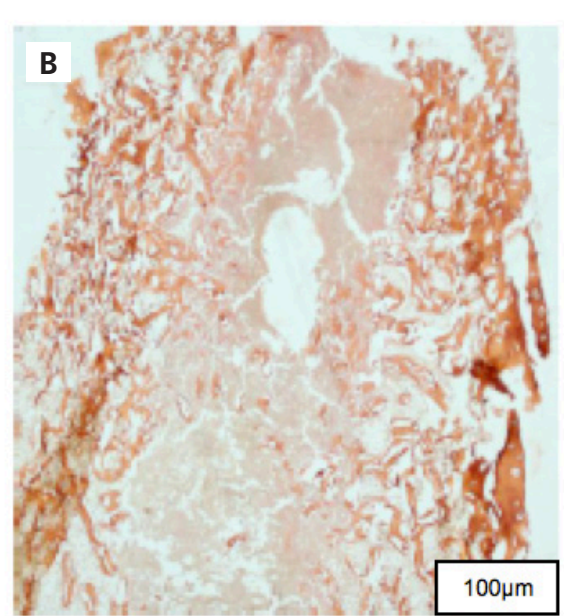

Figure 4. A) Piezo group 7 days - The presence can be observed of scattered bone trabeculae in the final third of the surgical site of preparation; B) Drill cutter group 7 days - The presence of newly formed trabeculae can be observed across the entire surgical site.

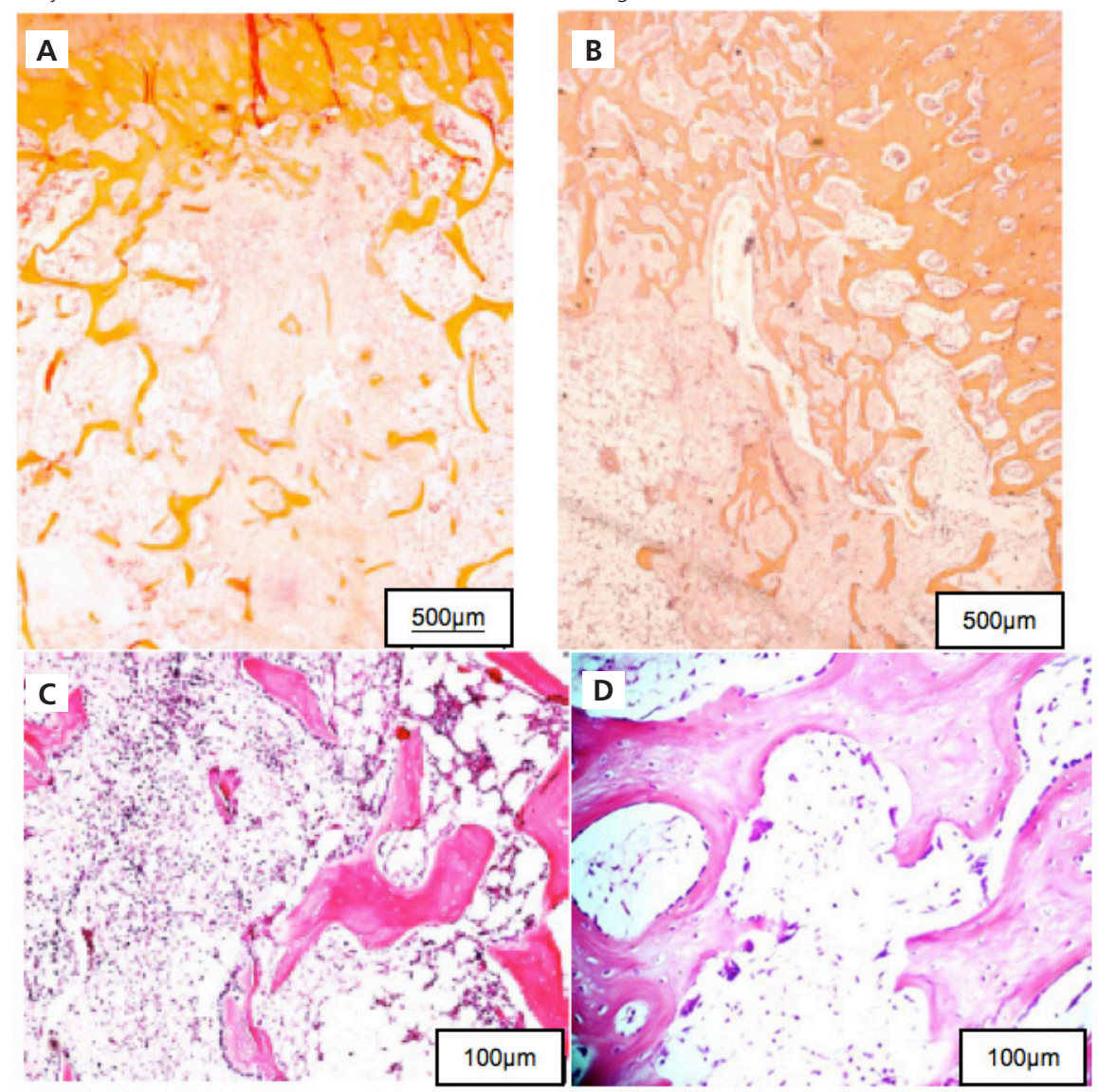

Figure 5. A) Piezo group 14 days - Image evidencing the presence of scattered bone trabeculae in the surgical site; B) Piezo group 14 days - Detail of the section between the old bone tissue and the newly formed tissue, with barely visible trabeculae; C) Piezo group 14 days - Image evidencing bone neoformation with intense trabeculae, suggesting a structural reorganization; D) Drill cutter group 14 days - Detail of mature trabeculae with secondary lamellar formation and osteoblastic lines in extreme deposition. 
At 28 days, the presence of mature bone tissue was noted in both groups with the presence of osteocytes,

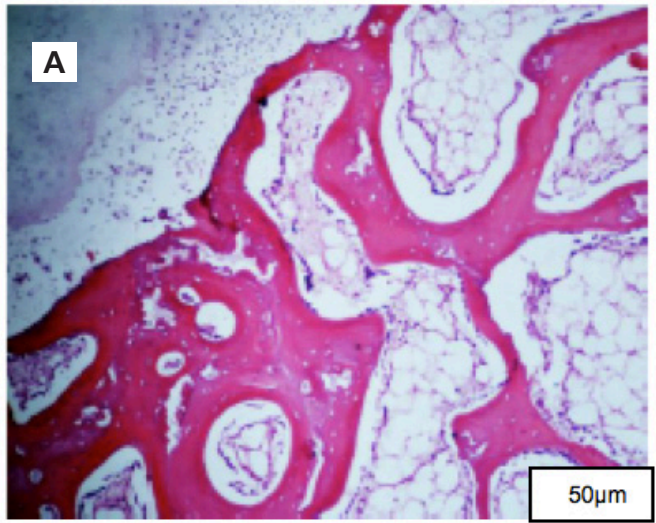

osteoblast lines and areas of bone apposition, enveloping the fatty marrow (Figures $6 \mathrm{~A}$ and $\mathrm{B}$ ).

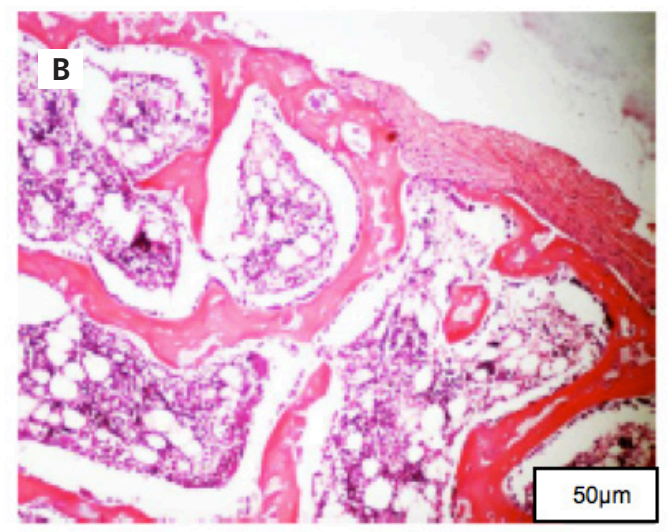

Figure 6. A) Piezo group 28 days; B) Drill cutter group 28 days. The two groups show details of the bone trabeculae in the surgical site, evidencing mature bone tissue with osteocytes and an osteoblastic lines.

\section{DISCUSSION}

This study made a histomorphological comparison of implant site preparations carried out with the piezoelectric system and with conventional rotary instruments using drill cutters, and taking different postoperative times into account. Few in vivo studies in the literature have conducted an evaluation of the histological aspects after the use of piezoelectric instruments in comparison with the conventional rotary cutting system, when preparing sites for implants ${ }^{21-24}$. It is important to emphasize that a direct comparison between the results of the present study and other, earlier studies is hindered by virtue of the different materials and methodologies employed and the distinct experimental models.

The histological analysis of the samples in the initial 2 to 7 day period revealed similar patterns in both the studied groups, evidencing the presence of a tissue consistent with a clot, along with an inflammatory infiltrate in the osteotomized section. The differences were pronounced only at 14 days. Greater bone neoformation was observed in the group of rotary instruments along the entire surgical site, while in the group of site preparations conducted using the piezoelectric system, scattered bone neoformation was observed.

The present results differ from earlier studies ${ }^{21,25}$, in which piezoelectric surgery promoted greater response in the initial phases of healing, with an increase in bone morphogenetic proteins interceding in the inflammatory process. In the present study, better healing was observed with the rotary instrument group. Von See et al. ${ }^{26}$, in a study using rats, noted a perfusion failure in the area of the osteotomy, through an analysis of intraosseous vessels which demonstrated an absence of blood flow at the edges of the osteotomies. This fact may explain the delay in bone neoformation observed when using the piezoelectric system in the present research study, in comparison with rotary instruments, primarily at 7 and 14 days. It is important to stress that at 28 days, in both groups, the presence of reorganized bone trabeculae was evident.

The results of the analysis of the osteotomized surface in the initial third of the site preparations conducted using the piezoelectric system were irregular, while the osteotomized surface using rotary instruments exhibited normal contours. Previous studies also observed coarser (irregular) bony surfaces in the osteotomized region with cuts using the piezoelectric system when compared to the oscillating saws, resulting in retarded bone regeneration ${ }^{19,27}$. On the other hand, conflicting results were reported by Heinemann et al. ${ }^{28}$. These authors compared the effects of osteotomies conducted using sonic, ultrasonic and conventional instruments by analyzing the degree of damage to the bone tissue in three different thirds. The results showed that the implant site preparation carried out using conventional instruments presented abnormal surfaces, compression of the trabeculae, however the underlying osteocytes were found to be intact and the bottom of the site of the preparation evidenced 
a zone of damage around 10 micrometers in diameter. The piezoelectric system resulted in a funnel-shaped preparation, with smooth surfaces and defects only in the lower third, with damage of around 30 micrometers in diameter, and the osteocyte zone intact. De Santis et al. ${ }^{23}$ found, in their histological analyses of an in vivo experiment conducted on rabbits, that the osteotomy performed with a laser and piezoelectric instruments (Piezosurgery II) resulted in greater damage to the osteocytes close to the osteotomized surface.

The results of the present study are similar to those obtained in a recent in vivo study conducted on rabbits, which evaluated the bone remodeling surrounding the dental implants in sites prepared using piezoelectric and conventional instruments. The authors found no difference between the two groups in terms of the number of bone trabeculae at the three points of evaluation $(7,14$ and 28 days). There was a significant increase in the number of bone trabeculae between 7 and 14 days, observed in both groups, corresponding to the period of greatest bone formation after the trauma produced following the osteotomies. Similarly, there was no significant difference between the area of contact between bone and implant, however this area was significantly smaller in the group of conventional cutting instruments at 7 and at 14 days. At the end of the study, after 28 days, the authors concluded that there was no difference between the piezoelectric and conventional instruments ${ }^{24}$. In another study previously carried out on beagles, Bengazi et al. ${ }^{22}$ also found that osseointegration of implants is possible if the sites are prepared using conventional drill cutters with copious irrigation or by means of piezoelectric surgery. Results of previously conducted in vitro ${ }^{29}$ and ex vivo ${ }^{30}$ studies also evidenced that conventional osteotomy and osteotomy by means of piezoelectric surgery are equally safe methods for preparing sites for dental implants.

\section{REFERENCES}

1. Pereira CC, Gealh WC, Meorin-Nogueira L, Garcia Junior IR, Okamoto R. Piezosurgery applied to implant dentistry: clinical and biological aspects. J Oral Implantol. 2014;40(Spec No.):401-8.

2. Sortino F, Pedullà E, Masoli V. The piezoelectric and rotatory osteotomy technique in impacted third molar surgery: comparison of postoperative recovery. J Maxillofac Surg. 2008;66(12):2444-8. doi:10.1016/j.joms.2008.06.004

3. Goyal M, Marya K, Jhamb A, Chawla S, Sonoo PR, Singh V, et al. Comparative evaluation of surgical outcome after removal of impacted mandibular third molars using Piezotome or a
On basis of the present data, it is possible to infer that the piezoelectric system is a viable alternative in the preparation of sites for the insertion of dental implants. The biggest limitation of piezosurgery is the time factor. On the other hand it has the advantage of the presence of an operative field free from bleeding.

\section{CONCLUSION}

Based on the results of the histological analysis, it was possible to conclude that bone neoformation was more evident in implant site preparations performed with conventional instruments, however both the conventional and piezoelectric instruments fostered similar bone neoformation, evidencing the presence of reorganized bone trabeculae after 28 days.

\section{Acknowledgments}

The authors wish to thank DSP Biomedical ${ }^{\circledR}$, Granja RG, the teams at the Animal Research Laboratories at the Heart Institute at the USP Medical School, the Electron Microscope Laboratory at the USP Institute of Biological Sciences and the Neuroscience Laboratory at the Department of Anatomy at the USP Institute of Biomedical Sciences III, for all the support given in the performance of this study.

\section{Collaborators}

GS was responsible for the experimental phase and in writing the article. MBS, MPCB, LYP and RMF participated in the preparation and in discussion of the results. MY and SAJ supervised the research and participated in writing the paper.

conventional handpiece: a prospective study. $\mathrm{Br} J$ Oral Maxillofac Surg. 2012; 50(6):556-61. doi:10.1016/j.bjoms.2011.10.010

4. Tsai SJ, Chen YL, Chang HH, Shyu YC, Lin CP. Effect of piezoelectric instruments on healing propensity of alveolar sockets following mandibular third molar extraction. J Dent Sci. 2012;7(3):296-300. doi:10.1016/j.jds.2012.07.001

5. Bartuli FN, Luciani F, Caddeo F, DE Chiara L, DI Dio M, Piva P, et al. Piezosurgery vs High Speed Rotary Handpiece: a comparison between the two techniques in the impacted third molar surgery. Oral Implantol. 2013;6(1):5-10.

6. Rullo R, Addabbo F, Papaccio, D'Aquino R, Festa VM. Piezoeletric device vs. conventional rotative instruments in impacted third molar surgery: relationships between surgical 
difficulty and postoperative pain with histological evaluations. J Craniomaxillofac Surg. 2013;41(2):e33-e38. doi:10.1016/j. jcms.2012.07.007

7. Robiony M, Polini F, Costa F, Vercellotti T, Politi M. Piezoelectric bone cutting in multipiece maxillary osteotomies. J Oral Maxillofac Surg. 2004;62(6):759-61. doi:10.1016/j.joms.2004.01.010

8. Gleizal A, Bera JC, Lavandier B, Beziat JL. Piezoelectric osteotomy: a new technique for bone surgery-advantages in craniofacial surgery. Childs Nerv Syst. 2007;23(5):509-13. doi:10.1007/ s00381-006-0250-0

9. Beziat JL, Bera JC, Lavandier B, Gleizal A. Ultrasonic osteotomy as a new technique in craniomaxillofacial surgery. Int J Oral Maxillofac Surg. 2007;36(6):493-500.

10. Robiony M, Polini F, Costa F, Zerman N, Politi M. Ultrasonic bone cutting for surgically assisted rapid maxillary expansion (SARME) under local anaesthesia. Int J Oral Maxillofac Surg. 2007;36(3):267-9.

11. Bertossi $D$, Luchesse $A$, Albanese $M$, Turra $M$, Faccioni $F$, Nocini $P$, et al. Piezosurgery versus conventional osteotomy in orthognathic surgery: a paradigm shift in treatment. J Craniofac Surg. 2013;24(5):1763-6. doi: 10.1097/SCS.0b013e31828f1aa8

12. Vercellotti T, Podesta A. Orthodontic microsurgery: a new surgically guided technique for dental movement. Int J Periodontics Restorative Dent. 2007;27(4):325-31.

13. Chiriac G, Herten M, Schwarz F, Rothamel D, Becker J. Autogenous bone chips: influence of a new piezoelectric device (Piezosurgery) on chip morphology, cell viability and differentiation. Clin Periodontol. 2005;32(9): 994-9. doi:10.1111/j.1600-051X.2005.00809.x

14. Sivolella S, Berengo M, Scarin M, Mella F, Martinelli F. Autogenous particulate bone collected with a piezo-electric surgical device and bone trap: a microbiological and histomorphometric study. Arch Oral Biol. 2006;51(10):883-91.

15. Sohn DS, Ahn MR, Lee WH, Yeo DS, Lim SY. Piezoelectric osteotomy for intraoral harvesting of bone blocks. Int J Periodontics Restorative Dent. 2007;27(2):127-31.

16. Baldi D, Menini M, Pera F, Ravera G, Pera P. Sinus floor elevation using osteotomes or piezoelectric surgery. Int J Oral Maxillofac Surg. 2011;40(5):497-503. doi: 10.1016/j.ijom.2011.01.006

17. Cortes AR, Cortes DN, Arita ES. Effectiveness of piezoelectric surgery in preparing the lateral window for maxillary sinus augmentation in patients with sinus anatomical variations: a case series. Int J Oral Maxillofac Implants. 2012;27(5):1211-5.

18. Rickert D, Vissink A, Huddleston Slater JJR, Meijer HJA, Raghoebar GM. Comparison between conventional and piezoelectric surgical tools for maxillary sinus floor elevation. A randomized controlled clinical trial. Clin Oral Implants Res. 2013;15(2):297-302. doi:10.1111/j.1708-8208.2011.00364.x

19. Metzger $M C$, Bormann KH, Schoen $R$, Gellrich NC, Schmelzeisen R. Inferior alveolar nerve transposition - an in vitro comparison between piezosurgery and conventional bur use. J Oral Implantol. 2006;32(1):19-25. doi:10.1563/15481336(2006)32[19:IANTIV]2.0.CO;2
20. Bovi M, Manni A, Mavriqi L, Celletti R. The use of piezosurgery to mobilize the mandibular alveolar nerve followed immediately by implant insertion: a case series evaluating neurosensory disturbance. Int J Periodontics Restorative Dent. 2010;30(1):73-81.

21. Preti G, Martinasso G, Peirone B, Navone R, Manzella C, Muzio $G$, et al. Cytokines and growth factors involved in the osseointegration of oral titanium implants positioned using piezoelectric bone surgery versus a drill technique: a pilot study in minipigs. J Periodontol 2007;78(4):716-22. doi:10.1902/ jop.2007.060285

22. Bengazi $F$, Lang NP, Canciani E, Viganò P, Velez JU, Botticelli D. Osseointegration of implants with dendrimers surface characteristics installed conventionally or with piezosurgery®. A comparative study in the dog. Clin Oral Implants Res. 2012;25(1):10-5. doi:10.1111/clr.12082

23. De Santis D, Gerosa R, Zanotti G, Cigikov N, Cenzi A, Chiarini $L$, et al. Experimental analysis about the evaluation of tungsten carbide-bur, piezoelectric and laser osteotomies. Minerva Stomatol. 2013 Aug 1. [Epub ahead of print].

24. Kfouri FA, Duailibi MT, Bretos JLG, Carvalho AB, Pallos D, Duailibi $\mathrm{SE}$. Piezoelectric osteotomy for the placement of titanium implants in rabbits: histomorphometry study. Clin Oral Implants Res. 2014;25(10):1182-8. doi: 10.1111/clr.12229

25. Tetè $S$, Vinci R, Zizzari V, Cingano L, Bollero R, D'Apolito G, et al. Evaluation of effects on bone tissue of different osteotomy techniques. J Craniofac Surg. 2009;20(5):1424-9. doi:10.1097/ SCS.0b013e3181aee3d3

26. von See $C$, Gellrich NC, Rücker $M$, Kokemüller $H$, Kober $H$, Stöver E. Investigation of perfusion in osseous vessels in close vicinity to piezo-electric bone cutting. Br J Oral Maxillofac Surg. 2012;50(3):251-5. doi:10.1016/j.bjoms.2011.04.069

27. Aro $\mathrm{H}$, Kallionemi $\mathrm{H}$, Aho AJ, Kellokumpu-Lehtinen P. Ultrasonic device in bone cutting. A histological and scanning electron microscopical study. Acta Orthop Scand. 1981;52(1):5-10.

28. Heinemann F, Hasan I, Kunert-Keil C, Götz W, Gedrange T, Spassov A, et al. Experimental and histological investigations of the bone using two different oscillating osteotomy techniques compared with conventional rotary osteotomy. Ann Anat. 2012;194(2):165-70. doi:10.1016/j.aanat.2011.10.005

29. Rashad A, Kaiser A, Prochnow N, Schmitz I, Hoffmann E, Maurer $P$. Heat production during different ultrasonic and conventional osteotomy preparations for dental implants. Clin Oral Implants Res. 2011;22(12):1361-5. doi:10.1111/j.16000501.2010.02126.x

30. Baker JA, Vora S, Bairam L, Kim HI, Davis EL, Andreana S. Piezoelectric vs. conventional implant site preparation: ex vivo implant primary stability. Clin Oral Implants Res. 2012;23(4):433-7. 